\author{
(1) Fatma İrem Yeşiler, \\ (D) Beyza Meltem Yurtsever, \\ (D) Ender Gedik, \\ (D) Pınar Zeyneloğlu, \\ (D) Mehmet Haberal
}

\section{A Novel Therapeutic Approach for Renal Transplant Recipient with Septic Shock and Acute Kidney Injury: A Case Report}

\author{
Septik Şok ve Akut Böbrek Hasarı Olan Böbrek Nakil \\ Alıcısında Yeni Bir Terapötik Yaklaşım: Bir Olgu ile
}

Received/Geliş Tarihi : 06.11.2020

Accepted/Kabul Tarihi : 07.02.2021

${ }^{\circ}$ Copyright 2021 by Turkish Society of Intensive Care Turkish Journal of Intensive Care published by Galenos Publishing House.

Fatma Irem Yeşiler, Beyza Meltem Yurtsever, Ender Gedik, Pınar Zeyneloğlu

Başkent University Faculty of Medicine, Department of Anesthesiology and Reanimation, Ankara, Turkey

Mehmet Haberal

Bașkent University Faculty of Medicine, Department of General Surgery, Division of Transplantation, Ankara, Turkey

Fatma Irem Yeşiler MD, (函,

Başkent University Faculty of Medicine, Department of Anesthesiology and Reanimation, Ankara, Turkey

E-mail : fatmairem84@hotmail.com

Phone : : +905053136518

ORCID ID : orcid.org/0000-0002-0612-8481
ABSTRACT Extracorporeal blood purification (EBP) therapies, using oXiris ${ }^{\circledR}$ haemofilter, are popular and used globally in intensive care units for management of patients with septic acute kidney injury (AKI). Herein, we present a case of an immunocompromised renal transplant recipient with sepsis and AKI who was treated with continuous renal replacement therapy (CRRT) using oXiris ${ }^{\circledR}$ haemofilter. A 45-year-old female who underwent cadaveric renal transplantation in 2015 was admitted due to septic shock secondary to Escherichia coli urinary tract infection (bacteraemia) and acute respiratory distress syndrome (ARDS). Her acute physiology and chronic health assessment score was 23, sepsis-related organ failure score was 11 and Glasgow coma scale was 15. She was intubated because of moderate ARDS and administered vasopressors due to hemodynamic instability. For immunosuppressive therapy, methylprednisolone (40 mg q12h) was administered. Antimicrobial therapies, including intravenous meropenem, linezolid, trimethoprimsulfamethoxazole, voriconazole and oseltamivir, were administered. She exhibited metabolic acidosis and septic AKI and was classified as Kidney Disease Improving Global Outcomes stage 3. Therefore, CRRT with oXiris ${ }^{\circledR}$ haemofilter was administered at the $11^{\text {th }}$ hour after admission. A full recovery of transplant renal function and diuresis was observed 7 days after admission. She was transferred to ward after 9 days and discharged after 2 weeks, without the requirement of RRT. EBP is proposed as an adjuvant therapy for sepsis and AKI. Solid organ transplant recipients with septic AKI may benefit from early usage of oXiris ${ }^{\circledR}$ haemofilter with CRRT as a novel approach for improving survival and clinical outcomes.

Keywords: Sepsis, acute kidney injury, renal replacement therapy, renal transplant recipient, extracorporeal blood purification

ÖZ oXiris ${ }^{\circledR}$ hemofiltre gibi ekstrakorporeal tedavi (ET) yöntemlerinin kullanımı, özellikle yoğun bakım ünitelerinde septik akut böbrek hasarı $(\mathrm{ABH})$ olan hastaların yönetiminde giderek artmaktadır. Sepsis ve $\mathrm{ABH}$ olan immünosüprese böbrek nakil alıcısında oXiris ${ }^{\circledR}$ hemofiltre ile sürekli renal replasman tedavisinin (SRRT) etkin kullanımını göstermeyi amaçladık. 2015 yılında kadavradan böbrek transplantasyonu yapılan 45 yaşında kadın hasta, akut solunum sıkıntısı sendromu (ARDS) ve Escherichia coli'ye bağlı idrar yolu enfeksiyonu nedeniyle septik şok ile yoğun bakım ünitesine kabul edildi. Akut fizyoloji ve kronik sağlık değerlendirme skoru 23, sepsise bağı organ yetersizliği skoru 11 ve Glasgow koma skalası 15 idi. Orta derecede ARDS nedeniyle entübe edildi ve hemodinamik disfonksiyon nedeniyle vazopresör desteği başlandı. Immünosüpresif tedavi için metilprednizolon 2×40 mg uygulandı. Intravenöz meropenem, linezolid, trimetoprim-sülfametoksazol, vorikonazol ve oseltamivir ile çoklu antimikrobiyal tedavi uygulandı. Septik $A B H$ ve metabolik asidozu mevcuttu. Böbrek hastalığı; Küresel Sonuçları lyileştirilmesi Çalışma Grubu'na göre evre 3 olarak sınıflandırıldı ve yoğun bakım ünitesine kabulden sonraki 11. saatte oXiris ${ }^{\circledR}$ hemofiltre ile SRRT başlandı. Kabulden 7 gün sonra transplante böbrek fonksiyonunda ve diürezde tam bir iyileşme gözlendi. Dokuz gün sonra servise devredildi ve 2 hafta sonra RRT ihtiyacı olmadan taburcu edildi. ET, sepsis ve ABH için adjuvan bir tedavi olarak önerilmektedir. Yeni bir tedavi yöntemi olarak oXiris ${ }^{\circledR}$ hemofiltre ile SRRT'nin erken kullanımı, septik ABH olan solid organ nakil alıcılarında sağkalımı ve klinik sonuçları iyileştirebilir.

Anahtar Kelimeler: Sepsis, akut böbrek hasarı, renal replasman tedavisi, böbrek nakil alıcısı, ekstrakorporeal tedavi 


\section{Introduction}

Sepsis is one of the most important causes of acute kidney injury (AKI) in intensive care unit (ICU). It can be seen in approximately $50 \%$ of critically ill patients with severe AKI $(1,2)$. If a patient with septic AKI has hemodynamic instability and/or fluid overload, continuous renal replacement therapy (CRRT) is recommended for treatment (3).

Extracorporeal blood purification (EBP) is suggested as an adjuvant therapy for sepsis aimed at correcting organ dysfunctions associated with the dysregulated immune system (4). The oXiris ${ }^{\circledR}$ hemofilter has a high permeability polyacrylonitrile (AN69) based membrane $(1,5)$. It is a next-generation EBP device that has high adsorption capacity for CRRT and both endotoxins and cytokine removal (5-7).

Several cytokines such as interleukin-1 (IL-1), IL-6 and tumor necrosis factor-alpha (TNF- $\alpha$ ) increase in sepsis. There is a significant relationship between increased levels of these cytokines and morbidity and mortality. oXiris ${ }^{\circledR}$ hemofilter purifies the majority of immune system mediators. There are in vitro filtration and observational studies showing that all IL-10 and $90 \%$ of IL- 6 and TNF- $\alpha$ are removed from the blood (8). Endotoxin adsorption is an innovative approach involved in management of sepsis. It controls the systemic inflammatory response that causes acute tissue and organ damage in sepsis (9).

The use of EBP therapies such as oXiris ${ }^{\circledR}$ hemofilter for management of septic AKI patients are popular worldwide in intensive care settings. Mondhe et al. (10) presented a poster describing the use of oXiris ${ }^{\circledR}$ hemofilter in a liver transplant recipient with sepsis and AKI. We present a successful clinical report of an immunocompromised renal transplant recipient with sepsis and AKI treated with CRRT using a oXiris ${ }^{\circledR}$ hemofilter.

\section{Case Report}

A 45-year-old female was hospitalized with nausea, vomiting and dysuria. Empirical antibiotic treatment was started with ertapenem due to urinary tract infection. The patient was admitted to ICU from the ward due to rapid deterioration of her clinical status. She had metabolic acidosis, respiratory distress and severe hemodynamic instability with need for vasopressor support. In the medical history, she had hypertension, diabetes mellitus type 2 and she underwent cadaveric renal transplantation 4 years ago. The patient has given her written informed consent to publish her case (including publication of images).

On physical examination, she was awake at ICU admission. Her vitals were as follows: Heart rate: 125/ minute, respiratory rate: 32/min, and blood pressure: 69/43 $\mathrm{mmHg}$ and body temperature (axillary measurement) $36.5^{\circ} \mathrm{C}$. In lung auscultation, coarse rales were present in the middle-lower areas of both hemithorax. Acute Physiology and Chronic Health Assessment-II (APACHE-II) score was 23, Sequential Organ Failure Assessment (SOFA) score was 11 and Glasgow coma score (GCS) was 15. Arterial blood gas $(A B G)$ was $p H: 7.22$, partial oxygen pressure $\left(\mathrm{PaO}_{2}\right)$ : $62.3 \mathrm{mmHG}$, partial carbon dioxide pressure $\left(\mathrm{PaCO}_{2}\right): 26.3$ $\mathrm{mmHg}$, bicarbonate $\left(\mathrm{HCO}_{3}\right): 9.8 \mathrm{mmol} / \mathrm{L}$, lactate: $1.7 \mathrm{mmol} / \mathrm{L}$, oxygen saturation $\left(\mathrm{SaO}_{2}\right): 90.8 \%$ under nasal oxygen therapy of $6 \mathrm{It} / \mathrm{min}$ at ICU admission. $\mathrm{PaO}_{2} / \mathrm{FiO}_{2}$ (inspired oxygen fraction) ratio was 141.5 in accordance with moderate acute respiratory distress syndrome (ARDS). Chest X-ray showed bilateral patchy infiltrates on the middle-lower areas of both hemithorax and computerized tomography of the thorax confirmed bilateral patchy alveolar infiltrates, ground-glasses and consolidations (Figure 1).

The hemodynamic status was instable so, norepinephrine infusion was started at $0.1 \mu \mathrm{g} / \mathrm{kg} / \mathrm{min}$ and rapidly increased to $1.5 \mu \mathrm{g} / \mathrm{kg} / \mathrm{min}$, in combination with dobutamine infusion at $5 \mu \mathrm{g} / \mathrm{kg} / \mathrm{min}$. An advanced hemodynamic monitoring system (Most Care ${ }^{\circledR}$ powered by Pressure Recording Analytical Method, PRAM; Vytech Health ${ }^{\circledR}$, Padova, Italy) was applied. She was treated according to the sepsis bundle guidelines, including administration of hydrocortisone dosages $(200 \mathrm{mg} /$ day on 4 days) for septic shock. Then, methylprednisolone
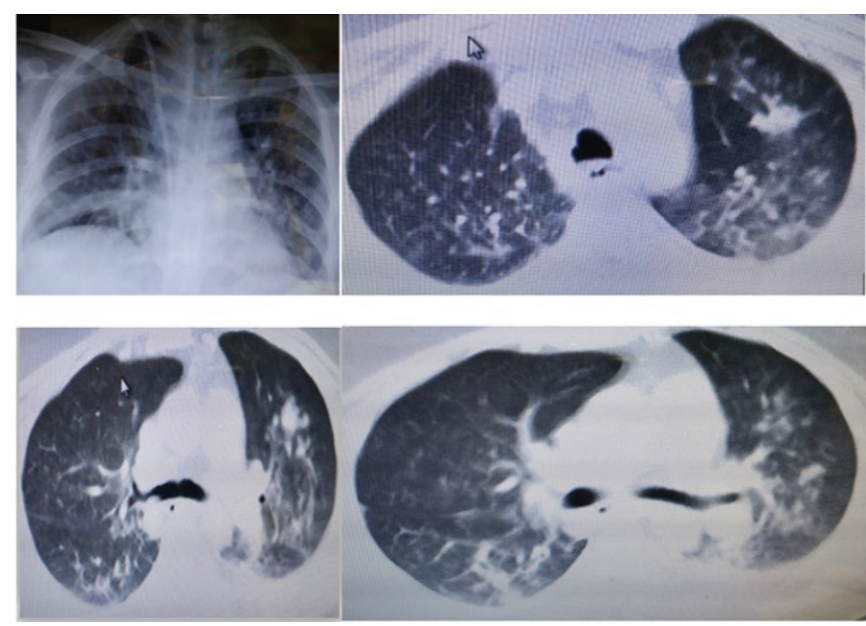

Figure 1. Chest X-ray and computerized tomography of the thorax 
was administered $40 \mathrm{gm} \mathrm{q12h}$ for 9 days. She was intubated $5^{\text {th }}$ hour after ICU admission because of moderate ARDS and ventilated by intellivent adaptive support ventilation mode for 6 days.

Laboratory parameters were presented in Table 1. There were elevated inflammatory marker plasma levels, increased blood urea nitrogen and serum creatinine. ABG analysis revealed metabolic acidosis on ICU admission (pH: 7.22, $\mathrm{pCO}_{2}$ : $24.4 \mathrm{mmHg}$, base excess: $-16.3 \mathrm{mmol} / \mathrm{L}$, $\mathrm{HCO}_{3}: 9.8 \mathrm{mmol} / \mathrm{L}$, lactate: $\left.1.7 \mathrm{mmol} / \mathrm{L}\right)$. Renal biopsy was performed, and infection-associated acute tubulointerstitial nephritis was diagnosed.

Due to a further increase in retention parameters and metabolic acidosis, she was classified as Kidney Disease Improving Global Outcomes (KDIGO) stage 3, so she received CRRT for the following 7 days. Continuous venovenous hemodiafiltration (CVVHDF) using Prismaflex CRRT machine (Baxter, Deerfield, IL, USA and Gambro Hospal, Stockholm, Sweden) and the oXiris ${ }^{\circledR}$ hemofilter with citrate anticoagulant was initiated at $11^{\text {th }}$ hour of admission to the ICU and it was stopped at $96^{\text {th }}$ hour of treatment. Due to volume overload, ultrafiltration was attempted and was successfully established at $50-250 \mathrm{~mL} / \mathrm{h}$ in order to reduce the positive fluid balance. Blood flows was set at $100 \mathrm{~mL} / \mathrm{min}$ and dialysis maintained in the range of $25-30 \mathrm{~mL} / \mathrm{kg} / \mathrm{h}$ (Table 2). The CVVHDF was stopped after 168 hours because of renal recovery. The therapy ensured a progressive improvement in her hemodynamic status and a reduction vasopressor requirements (Table 3 ).

Escherichia coli was isolated in the blood and the urine culture. Antimicrobial therapy with intravenously meropenem (2 gram every 8 h) for 13 days, linezolid (600 mg every 12 h) for 8 days, trimethoprim-sulfamethoxazole $(400 \mathrm{mg}$ every 8 h-dosing is based upon the trimethoprim component) for 14 days, oral voriconazole (200 mg every 12 h) 14 days and oral oseltamivir ( $75 \mathrm{mg}$ every $12 \mathrm{~h}$ ) for 5 days were administered. Polymerase chain reaction tests of influenza type $A-B$,

\begin{tabular}{|c|c|c|c|c|c|c|c|c|c|}
\hline Day & $1^{\text {st }}$ day & $2^{\text {nd }}$ day & $3^{\text {rd day }}$ & $4^{\text {th }}$ day & $5^{\text {th }}$ day & $6^{\text {th }}$ day & $7^{\text {th }}$ day & $8^{\text {th }}$ day & $9^{\text {th }}$ day \\
\hline $\mathrm{Hgb}(\mathrm{g} / \mathrm{dL})$ & 10.2 & 8.8 & 9.9 & 10 & 10.2 & 9.5 & 8.7 & 7.9 & 9.3 \\
\hline Hct (\%) & 30.7 & 27.9 & 31 & 32.1 & 29 & 30.2 & 27.4 & 25.5 & 28.5 \\
\hline Platelet $\left(10^{3} / \mu \mathrm{l}\right)$ & 69 & 65 & 69 & 63 & 88 & 68 & 64 & 53 & 72 \\
\hline WBC $\left(10^{3} / \mu \mathrm{l}\right)$ & 10.8 & 17.1 & 16.7 & 13.8 & 17.2 & 16.3 & 10.8 & 5.36 & 5.98 \\
\hline PT (sec.) & 20.5 & 19.2 & 15 & 13.8 & 13 & 13.3 & 13.6 & 13.6 & 13.5 \\
\hline INR & 1.8 & 1.69 & 1.32 & 1.2 & 1.14 & 1.16 & 1.19 & 1.19 & 1.18 \\
\hline BUN (mg/dL) & 59.3 & 42 & 43 & 57 & 56 & 43 & 32 & 33 & 43 \\
\hline $\mathrm{Cr}(\mathrm{mg} / \mathrm{dL})$ & 3.88 & 3.03 & 2.11 & 2.07 & 1.78 & 1.62 & 1.22 & 1.39 & 2.11 \\
\hline $\mathrm{Na}(\mathrm{mg} / \mathrm{dL})$ & 138 & 133 & 133 & 130 & 130 & 133 & 130 & 135 & 136 \\
\hline $\mathrm{K}(\mathrm{mg} / \mathrm{dL})$ & 3 & 3.6 & 3.9 & 3.6 & 4 & 3.5 & 3.9 & 3.9 & 3.7 \\
\hline $\mathrm{Cl}(\mathrm{mg} / \mathrm{dL})$ & 103 & 99 & 98 & 96 & 95 & 98 & 97 & 102 & 104 \\
\hline$P(\mathrm{mg} / \mathrm{dL})$ & 4.78 & 3.2 & 3.7 & 3.4 & 4.3 & 4.3 & 2.6 & 1.9 & 3 \\
\hline Albumin (g/dL) & 2.9 & 2.9 & 3 & 2.9 & 3 & 2.8 & 2.7 & 2.5 & 2.5 \\
\hline AST (U/L) & 42 & 43 & 40 & 38 & 29 & 25 & 23 & 26 & 27 \\
\hline $\operatorname{ALT}(\mathrm{U} / \mathrm{L})$ & 8 & 19 & 19 & 15 & 14 & 11 & 11 & 13 & 16 \\
\hline T. bil (mg/dL) & 0.57 & 0.7 & 0.7 & 0.6 & 0.4 & 0.5 & 0.5 & 0.6 & 0.5 \\
\hline D. bil (mg/dL) & 0.42 & 0.3 & 0.4 & 0.4 & 0.2 & 0.3 & 0.5 & 0.2 & 0.2 \\
\hline Lactate (mmol/L) & 2.7 & & 1.2 & 1.2 & 1.9 & 1.4 & 0.9 & 1.3 & \\
\hline CRP (mg/L) & 337 & 525 & 361.1 & 242 & 141 & 77 & 70.7 & 43.4 & 28.3 \\
\hline PCT $(\mu \mathrm{g} / \mathrm{L})$ & 59 & - & 15 & - & 5.5 & - & 2.8 & - & 0.25 \\
\hline
\end{tabular}


respiratory syncytial virus and cytomegalovirus DNA were negative. Pneumocystis pneumonia was not detected in bronchoalveolar lavage.

She was extubated after 6 days. A recovery of transplant renal function and diuresis was observed evidenced by increasing urine output and decreasing serum creatinine, which resulted in the discontinuation of CVVHDF after 7 days from the admission. Her glomerular filtration rate was $37 \mathrm{~mL} / \mathrm{min}$ by the Cockcroft-Gault formula and $26.9 \mathrm{~mL} /$ $\mathrm{min} / 1.73 \mathrm{~m}^{2}$ by the Modification of Diet in Renal Diseases Study formula. She was transferred to ward after 9 days and discharged after 2 weeks without requirement for renal replacement therapy.

\section{Discussion}

Sepsis is a combination of organ dysfunctions that occur with infection. This dysregulated host response has physiologic, pathologic, and biochemical abnormalities. One of the most important recommendations in the management of sepsis is the urgent application of antibiotics within the first 3 hours of suspected sepsis (9). The first approach in the management of sepsis to control the source of infection by early and targeted intervention. The importance of endotoxin and cytokine removal in criticaly ill patients is increasing to improve outcomes (11). This case presented that the clinical situation improved with rapid infection source control, effective antibiotic administration, and early use of the oXiris ${ }^{\circledR}$ hemofilter with CRRT due to AKI within 6-24 hours of suspected sepsis.

oXiris ${ }^{\circledR}$ hemofilter is a combination of AN69based membrane hemofilter, surface treatment with polyethyleneimine and grafted with heparin. It removes cytokines and endotoxins from blood circulation $(12,13)$. Case series demonstrated that oXiris ${ }^{\circledR}$ hemofilter therapy reduced especially IL-6 level and improved hemodynamics

\begin{tabular}{|c|c|c|c|c|c|c|c|c|}
\hline Day & $1^{\text {st }}$ day & $2^{\text {nd }}$ day & $3^{\text {rd day }}$ & $4^{\text {th }}$ day & $5^{\text {th }}$ day & $6^{\text {th }}$ day & $7^{\text {th }}$ day & $8^{\text {th }}$ day \\
\hline $\mathrm{Q}_{\mathrm{b}}, \mathrm{mL} / \mathrm{min}$ & 100 & 100 & 100 & 100 & 100 & 100 & 100 & 100 \\
\hline $\mathrm{Q}_{\mathrm{d}} \mathrm{mL} / \mathrm{h}$ & 250 & 250 & 250 & $100-250$ & $250-500$ & 500 & 500 & 500 \\
\hline Predilution, mL/h & 1,500 & 1,500 & 1,500 & 1,500 & 1,500 & 1,500 & 1,500 & 1,500 \\
\hline Postdilution, mL/h & 250 & 250 & 250 & $100-250$ & 250 & 250 & 250 & 250 \\
\hline $\mathrm{Q}_{\mathrm{r}} \mathrm{mL} / \mathrm{h}$ & 1,750 & 1,750 & 1,750 & $1,600-1,750$ & 1,750 & 1,750 & 1,750 & 1,750 \\
\hline UF, mL/h & 0 & $50-250$ & 250 & 100 & $100-200$ & $50-70$ & 70 & 0 \\
\hline UO, mL/24 h & 10 & 40 & 20 & 40 & 5 & 1,180 & 1,510 & 4,200 \\
\hline
\end{tabular}

Table 3. Hemodynamic and arterial blood gas analysis during CRRT with oXiris ${ }^{\circledR}$ hemofilter

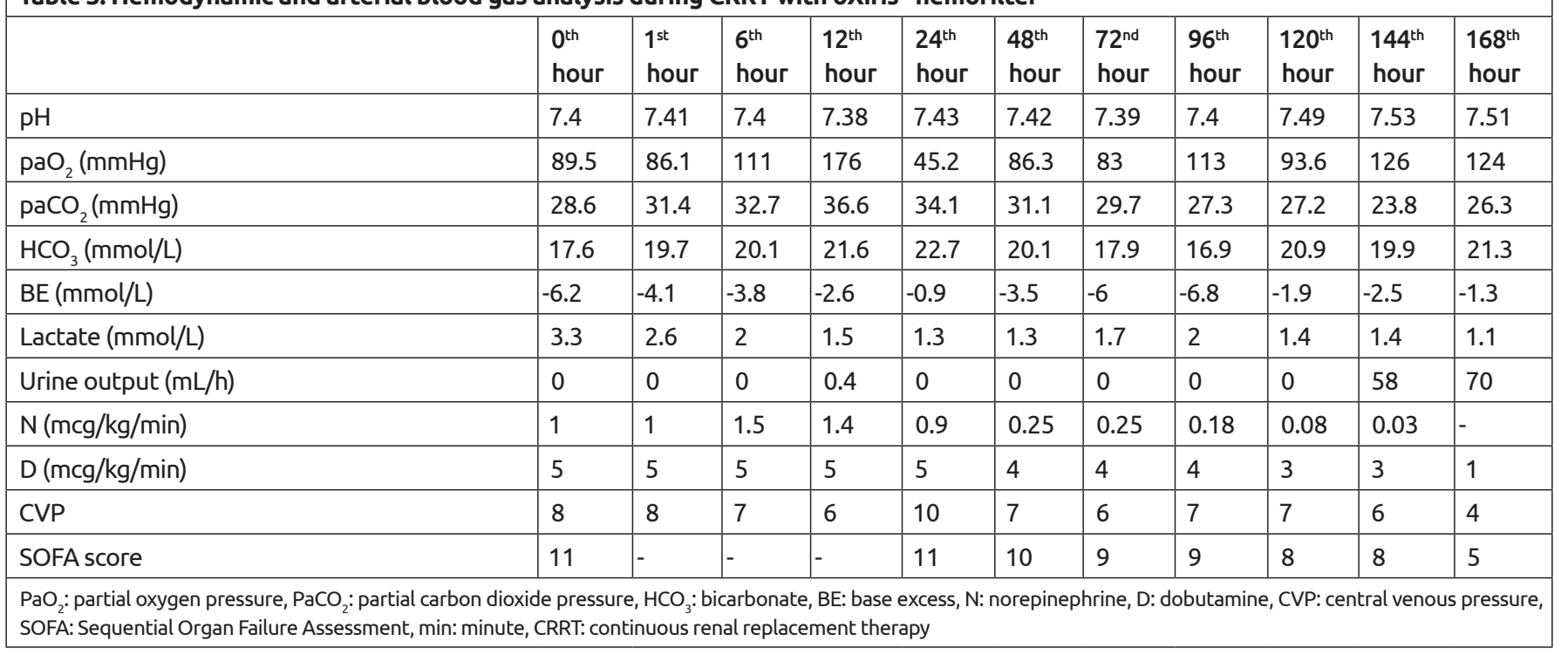


(7). So, oXiris ${ }^{\circledR}$ hemofilter can be considered as a supportive therapy in the treatment of sepsis.

We presented a patient with E. coli bacteremia who had decrease in SOFA score, improved hemodynamics and reduction of vasopressor requirements with oXiris ${ }^{\circledR}$ hemofilter therapy (Table 3). Our results were similar to most studies researching the oXiris ${ }^{\circledR}$ hemofilter (14-16). Schwindenhammer et al. (17) reported their experiences with 31 septic shock patients using CRRT and the oXiris ${ }^{\circledR}$ hemofilter. They found that the most severe patients who received CRRT therapy with the oXiris ${ }^{\circledR}$ hemofilter also had higher observed survival than predicted by a severity score (SAPS II). There are studies showing that it improves hemodynamic status and hyperlactathemia in Gram negative bacilli-induced intra-abdominal sepsis. In the study of Shum et al. (14), oXiris ${ }^{\circledR}$ hemofilter and continuous venovenous hemofiltration (CVVH) were performed in 6 patients with septic AKI caused by Gram negative bacteria. The SOFA score decreased significantly after 48 hours in the oXiris ${ }^{\circledR}$ group. A significant decrease in the SOFA score at 72 hours was also observed in the study of Adamik et al. (15). In our case, we reported a 3-point decrease in the SOFA score 72 hours after the treatment. Also, Shum et al. (14) presented that E. coli accounted for $100 \%$ (6 patients) in the oXiris$\mathrm{CVVH}$ group. The same bacteria from the blood and the urine culture of our patient was identified. Like our case, 4 patients with septic AKI who were applied renal replacement therapy with oXiris ${ }^{\circledR}$ hemofilter in China, were presented in the study of Zhang et al. (18). These cases in the literature and our case showed that the clinical condition of patients improved with rapid infection source control and the usage of oXiris ${ }^{\circledR}$ hemofilter within 6-24 hours in the management of suspected sepsis. Furthermore, 2 patients had gram negative sepsis as our patient.

Broman and Bodelsson (11) presented reduction of endotoxin levels after usage oXiris ${ }^{\circledR}$ hemofilter in 2 patients with Gram negative bacteria-induced septic shock including endotoxemia. KDIGO class 3 AKI was detected in both patients, and CRRT was started using an oXiris ${ }^{\circledR}$ hemofilter. Likewise, we presented a successful clinical report of an immunocompromised renal transplant recipient with gram negative septic shock and KDIGO grade 3-AKI treated with CRRT using a oXiris ${ }^{\circledast}$ hemofilter.

Determining the best time to start EBP with devices such as the oXiris ${ }^{\circledast}$ hemofilter is difficult and controversial. If a patient with septic AKI has a hyperinflammatory state and/or hemodynamic instability, early usage of EBP with the oXiris ${ }^{\circledR}$ hemofilter may be considered without waiting for diagnostic confirmation of abnormal biomarker levels. Of course, it should be done together with the source of infection and standard sepsis care (19).

The timing of EBP with the oXiris ${ }^{\circledR}$ hemofilter is an important key factor. In the study of Govil et al. (20), a significant difference was observed in the SOFA score and vasopressor decrease in the group that used early Oxiris hemofilter. oXiris ${ }^{\circledR}$ hemofilter inception time was shorter in survivors than non-survivors (7.2 vs 12.5 hours) in the study of Tang et al. (21). A clinical trial involving 15 septic patients who were applied CRRT with the oXiris ${ }^{\circledR}$ hemofilter reported that the early inception of therapy improved outcomes before the organ damage started (22). In this case, oXiris ${ }^{\circledR}$ hemofilter was used on $11^{\text {th }}$ hour after admission similar to literature.

oXiris ${ }^{\circledR}$ hemofilter improve hemodynamic status and lactate metabolism and increases respiratory capacity. The improvement is thought to be due to purification of cytokines, inflammatory mediators, endotoxin adsorption and the maintenance of fluid balance. In a clinical trial involving 40 septic patients who were applied CRRT with the oXiris ${ }^{\circledR}$ membrane, levels of procalcitonin, IL-6, endotoxin, norepinephrine and creatinine decreased after 24 hours of therapy (7). The dosage of noradrenaline is also decreased, as shown by Shum et al. (14) and Turani et al. (7). In our case, lactate level decreased in $6^{\text {th }}$ hour of therapy, creatine and norepinephrine levels decreased 24 hours after treatment, procalcitonin decreased 48 hours later and she was extubated after 6 days.

Normally, it is recommended to change the filter set every 24 hours to ensure the filter performance. The product label includes the replacement of the hemofilter to an upper limit of 72 hours and/or a maximum through put of $780 \mathrm{~L}$ of blood (5). However, we used the filter continuously for 96 hours with citrate anticoagulation.

Immunoparalysis is observed in immunocompromised patients. So, the use of EBP therapies may also represent a good adjunctive therapy option in these patients with sepsis and multiple organ failure. Keles et al. (23) reported the a successful administration of CytoSorb ${ }^{\circledR}$ hemadsorption in an immunocompromised pediatric patient with collapsing glomerulopathy, ARDS, and sepsis. There is limited data about the usage of oXiris $^{\circledR}$ hemofilter in immunocompromised adult patients in the literature. 
The case report has some limitations. There is no clinical study in which loss of antibiotics and micronutrients with CRRT using a highly adsorptive hemofilter like oXiris ${ }^{\circledR}$ hemofilter was reported. A close drug-monitoring should be performed to ensure appropriate antibiotic concentrations. But, the monitoring could not be done because the antibiotic levels are not studied comprehensively in our hospital. One of our limitations was that we could not measure endotoxin and cytokine levels, so we could not detect the decrease due to treatment. This presentation is only a case report. Randomised controlled trials about this therapy will provide more useful information.

This is a case report that includes the successful use of oXiris ${ }^{\circledR}$ hemofilter in a renal transplant recipient with septic AKI. The use of EBP therapies in acute phase of septic shock and septic AKI may be beneficial for early improvement, decreasing vasopressor requirment, need for organ supports, the length of ICU stay and mortality. So, EBP is proposed as an adjuvant therapy for sepsis and AKI. Solid organ transplant recipients with septic $A K I$ may benefit from early usage of oXiris ${ }^{\circledR}$ hemofilter with CRRT as a novel approach to improve survival and clinical outcomes. Further randomized control trials are recommended to prove the potential benefits of this treatment.

\section{Ethics}

Informed Consent: The patient has given her written informed consent to publish her case (including publication of images).

Peer-review: Externally peer-reviewed.

\section{Authorship Contributions}

Surgical and Medical Practices: M.H., Concept: E.G., P.Z., M.H., Design: E.G., P.Z., M.H., Data Collection or Processing: F.I.Y., B.M.Y., Analysis or Interpretation: F.I.Y., E.G., P.Z., Literature Search: F.I.Y., B.M.Y., Writing: F.I.Y., B.M.Y., E.G.

Conflict of Interest: No conflict of interest was declared by the authors.

Financial Disclosure: The authors declared that this study received no financial support. 


\section{References}

1. Case J, Khan S, Khalid R, Khan A. Epidemiology of acute kidney injury in the intensive care unit. Crit Care Res Pract 2013;2013:479730.

2. Bellomo R, Kellum JA, Ronco C, Wald R, Martensson J, Maiden M, et al. Acute kidney injury in sepsis. Intensive Care Med 2017:43:816-28.

3. Honore PM, Jacobs R, Joannes-Boyau O, De Regt J, Boer W, De Waele $E$, et al. Septic AKI in ICU patients. diagnosis, pathophysiology, and treatment type, dosing, and timing: a comprehensive review of recent and future developments. Ann Intensive Care 2011:1:32

4. Monard C, Rimmelé T, Ronco C. Extracorporeal Blood Purification Therapies for Sepsis. Blood Purif 2019;47 Suppl 3:1-14.

5. Gambro Industries. oXirisTM Instructions for use, 2015. https://www.baxter.com/ healthcare-professionals/critical-care/ oxiris-critical-care

6. Imahase $H$, Sakamoto $Y$, Kusunose M, Koami H, Nishimura $Y$, Goto A, et al. Examination of blood filtration membrane removal ability of HMGB1. Crit Care 2012;16(Suppl 3):1-58.

7. Turani F, Candidi F, Barchetta R, Grilli E, Belli A, Papi E, et al. Continuous renal replacement therapy with the adsorbent membrane oXiris in septic patients: a clinical experience. Crit Care 2013;17(Suppl 2):1-200.

8. Malard B, Lambert C, Kellum JA. In vitro comparison of the adsorption of inflammatory mediators by blood purification devices. Intensive Care Med Exp 2018;6:12.
9. Singer M, Deutschman CS, Seymour CW, Shankar-Hari M, Annane D, Bauer M, et al. The Third International Consensus Definitions for Sepsis and Septic Shock (Sepsis-3). JAMA 2016;315:801-10.

10. Mondhe S, Reddy PV, Gundlapalli S, Hedau S, Yachha M, Kumthekar G, et al. Experience of extracorporeal therapy OXIRIS for sepsis in indian tertiary care hospital. Twentieth International Conference on Advances in Critical Care Nephrology; 2017 Mar 7-10; Manchester Grand Hyatt San Diego, California. Available from: https://www.crrtonline. com/conference/posters_2017/95\%20 Suhas\%20Mondhe.pdf

11. Broman ME, Bodelsson M. Analysis of Endotoxin Adsorption in Two Swedish Patients with Septic Shock. Blood Purif 2019;47:1-3.

12. Chiu CT, Yeh YC. Blood purification in critically ill patients with sepsis and septic shock. J Emerg Crit Care Med 2018;2:77

13. Broman ME, Hansson F, Vincent JL, Bodelsson M. Endotoxin and cytokine reducing properties of the oXiris membrane in patients with septic shock: A randomized crossover double-blind study. PLoS One 2019;14:0220444.

14. Shum HP, Chan KC, Kwan MC, Yan WW. Application of endotoxin and cytokine adsorption haemofilter in septic acute kidney injury due to Gram-negative bacterial infection. Hong Kong Med J 2013;19:491-7.

15. Adamik BA, Smiechowicz JS, Zielinski SZ, Kübler AK. Use of extracorporeal endotoxin elimination therapy for septic shock. Crit Care 2013;17(Suppl 2):P66.

16. Tan HK, Kaushik M, Tan CW, Liew ZH, Teo SH, Loo CM, et al. Augmented
Adsorptive Blood Purification during Continuous Veno-Venous Haemodiafiltration in a Severe Septic, Acute Kidney Injury Patient: Use of oXiris $®$ : A Single Centre Case Report. Blood Purif 2019;47:1-6.

17. Schwindenhammer $V$, Girardot $T$, Chaulier K, Grégoire A, Monard C, Huriaux L, et al. oXiris $₫$ Use in Septic Shock: Experience of Two French Centres. Blood Purif 2019;47:1-7.

18. Zhang L, Yan Tang GK, Liu S, Cai J, Chan WM, Yang Y, et al. Hemofilter with Adsorptive Capacities: Case Report Series. Blood Purif 2019;47:1-6.

19. Turani F, Barchetta R, Falco M, Busatti S, Weltert L. Continuous Renal Replacement Therapy with the Adsorbing Filter oXiris in Septic Patients: A Case Series. Blood Purif 2019;47:1-5.

20. Govil D, Gupta S, Srinivasan S, Patel SJ, Jagadeesh KN, Shafi M, et al. Cytokine removal in sepsis: does their levels corelate with outcome. Kidney Int Rep 2017;2:S29.

21. Tang GKY, Ng PY, Tsai PNW, To HMH, Leung YYN, Chan WM. oXiris in sepsis: A case series in Hong Kong. Poster presented at: 2nd Asia Pacific AKI CRRT; 2018 p. 21-24; Taipei, Taiwan.

22. Govil D, Gupta S, Srinivasan S, Patel SJ, Jagadeesh KN, Shafi M, et al. Cytokine adsorption in sepsis: correct timing can predict the favorable outcome. Kidney Int Rep 2017;2:S29.

23. Keles E, Fidan K, Yenicesu I, Kalkan G. Successful application of CytoSorb ${ }^{\circledR}$ hemadsorption in an immunocompromised teenager with collapsing glomerulopathy, acute respiratory distress syndrome, and sepsis. Int J Artif Organs 2019;42:765-9. 